\title{
EFEKTIVITAS SENAM AEROBIK INTENSITAS SEDANG TERHADAP TEKANAN DARAH DAN KESEGARAN JASMANI PADA REMAJA OVERWEIGHT DI JURUSAN GIZI POLTEKKES KEMENKES SEMARANG
}

\author{
EFFECTIVENESS OF MODERATE INTENSITY AEROBIC EXERCISE ON BLOOD PRESSURE AND PHYSICAL FITNESS \\ IN OVERWEIGHT ADOLESCENTS AT THE NUTRITION DEPARTMENT POLTEKES KEMENKES SEMARANG
}

\author{
Winda Permatasari ${ }^{1}$, Enik Sulistyowati ${ }^{2}$, Yuwono Setiadi $^{2}$
}

\begin{abstract}
Background : Overweight is one nutritional status problem with excess body fat percent, has a prolonged impact on the risk of degenerative diseases. Overweight is one of factor that triggers hypertension and affects the physical fitness of the decreasing and easily tired.
\end{abstract}

Objective : To know the effectiveness of moderate intensity aerobic exercise on blood pressure and physical fitness of overweight adolescentsatthe Nutrition Department of PoltekkesKemenkes Semarang.

Methods : This study was one of community nutrition. True-Experimental with pre and post-control group design was used. Random sampling technique was used to get 17 treatment samples and 17 control samples. The collected data contained characteristics data, anthropometric (height, weight), Systolic Blood Pressure (SBP), Dyastolic Blood Pressure (DBP), Physical fitness, energy intake and physical activity. T-tests(paired t test and independent $t$ test) were analyzed to determine the differences between variables.

Results : After moderat intensity of aerobic exercise at 5 weeks, there was a significant different $(p<0,05)$ between treatment and control groups on physical fitness $(21,84 \pm 5,25 \mathrm{vs} 12,92 \pm 5,24 \mathrm{ml} / \mathrm{kg} / \mathrm{minutes})$. There were no differences $(p>0,05)$ for SBP $(113.47 \pm 9,47$ vs $117,17 \pm 13,11 \mathrm{mmHg})$ and $D B P(80,2 \pm 11,55 \mathrm{vs} 76,71 \pm 8,42 \mathrm{mmHg}$ ) in both of group.

Conclusion : There was a difference in the increase in physical fitness of the treatment group $p=0,000(p<0.05)$

Keywords : moderate aerobic aerobics, Blood Pressure, Physical Freshness, overweight

\section{ABSTRAK}

Latar Belakang : Masalah gizi lebih (kegemukan) merupakan salah satu masalah gizi dengan persen lemak tubuh berlebih, memiliki dampak berkepanjangan terhadap peningkatan resiko penyakit degeneratif. Kegemukan menjadi faktor pemicu penyakit Hipertensi dan berdampak pada penurunan kesegaran jasmani.

Tujuan : Untuk Mengetahui efektivitas senam aerobik intensitas sedang pada tekanan darah dan kesegaran jasmani pada mahasiswi overweight di Jurusan Gizi Poltekkes Kemenkes Semarang.

Metode : Penelitian ini termasuk penelitian gizi masyarakat. Desain penelitian ini menggunakan TrueEksperimental dengan pre dan post test control group. Penenetuan sampel menggunakan random sampling untuk mendapatkan 17 subjek perlakuan dan 17 subjek kontrol . Data yang dikumpulkan meliputi karakteristik umum, data antropometri (TB dan BB), Tekanan Darah, Kesegaran Jasmani, asupan energi dan aktivitas fisik. Analisis data yang digunakan adalah T-test (Paired $t$ test dan Indpendent $t$ test).

Hasil : Setelah diberikan senam aerobik intensitas sedang selama 5 minggu, terdapat perbedaan signifikan $(p<0,05)$ antara kelompok perlakuan dan kontrol pada kesegaran jasmani $(21,84 \pm 5,25$ vs $12,92 \pm 5,24$ $\mathrm{ml} / \mathrm{kg} / \mathrm{menit})$. Tekanan Darah Sistolik $(113.47 \pm 9,47$ vs $117,17 \pm 13,11 \mathrm{mmHg})$ dan Tekanan Darah Diastolik $(80,2 \pm 11,55$ vs $76,71 \pm 8,42 \mathrm{mmHg})$ pada kedua kelompok tidak berbeda signifikan $(p>0,05)$.

Kesimpulan : Ada perbedaan peningkatan pada kesegaran Jasmani kelompok perlakuan $p=0,000(p<0,05)$

Kata kunci : senam aerobik intensitas sedang, Tekanan Darah, Kesegaran Jasmani, overweight 


\section{PENDAHULUAN}

Masalah gizi di Indonesia saat ini dikenal dengan masalah gizi ganda (double burden). Disuatu sisi masalah gizi kurang masih banyak disisi lain masalah gizi lebih terus meningkat ${ }^{1}$. Masalah gizi lebih (kegemukan) merupakan salah satu masalah gizi status gizi dengan persen lemak tubuh berlebih, memiliki dampak berkepanjangan terhadap resiko terjadinya permasalahan kesehatan yaitu meningkatkan resiko penyakit degeneratif ${ }^{2}$. Hasil Riskesdas 2013 menunjukkan bahwa prevalensi gizi menurut Indeks Masa Tubuh (IMT) pada usia > 18 tahun secara nasional yaitu $28,90 \%$ yang terdiri dari $13,50 \%$ gemuk dan $15,40 \%$ obesitas. Di Provinsi Jawa Tengah, prevalensi gizi menurut IMT usia > 18 tahun yaitu 23,6\%. Prevalensi gizi lebih pada perempuan usia $>18$ tahun $30,2 \%$ dan pada laki-laki $16,8 \%^{3}$. Berdasarkan hasil survey yang dilakukan pada penelitian sebelumnya di Jurusan Gizi Poltekkes Kemenkes Semarang mahasiswa yang memiliki IMT > $23 \mathrm{~kg} / \mathrm{m}^{2}$ sebanyak 33 orang $(9,7 \%)^{4}$. Serta hasil survey penelitian pada bulan Maret 2017 didapatkan prevalensi remaja di Jurusan Gizi Poltekkes Kemenkes Semarang yang memiliki IMT $\geq 23 \mathrm{~kg} / \mathrm{m}^{2}$ meningkat sebanyak 57 orang (21,18\%) dari 269 orang 5 . Hal ini menunjukkan bahwa prevalensi gizi lebih pada remaja di Jurusan Gizi Poltekkes Kemenkes Semarang mendekati prevalensi gizi lebih di Jawa Tengah.

Remaja yang mengalami overweight memiliki resiko sebanyak $70 \%$ untuk mengalami overweight atau obesitas pada saat dewasa ${ }^{6}$. Overweight merupakan faktor resiko terjadinya penyakit-penyakit lain, seperti hipertensi, diabetes melitus, batu empedu dan lain-lain. Angka hipertensi di Indonesia mengalami peningkatan dari tahun ke tahun. Berdasarkan hasil Riset Kesehatan Dasar prevalensi hipertensi pada umur $\geq 18$ tahun di Indonesia didiagnosis tenaga kesehatan sebesar 9,4\%, prevalensi kasus peningkatan tekanan darah pada remaja didunia hampir mencapai $20 \%^{7}$, sedangkan berdasarkan pengukuran sebesar $25,8 \%{ }^{3}$. Peningkatan tekanan darah yang tidak dikontrol dan tidak ditangani dapat beranjut menjadi hipertensi dan meningkatkan risiko 2,03 kali untuk terkena penyakit jantung ${ }^{8-9}$. Pada orang yang overweight juga memiliki efek negatif karena lemak yang berlebihan akan meningkatkan nilai metabolik latihan, pergerakan tubuh terbatas, dan menurunkan aktivitas fisik. Berdasarkan hasil penelitian Ginting dan Utari dikatakan bahwa semakin tinggi Indeks Massa Tubuh, semakin rendah tingkat kesegaran jasmaninya. Kebugaran fisik (physical fitness) atau kesegaran jasmani, yakni kemampuan seseorang melakukan kerja sehari-hari secara efisien tanpa timbul kelelahan yang berlebihan sehingga masih dapat menikmati waktu luangnya 10,11. Kesegaran jasmani erat hubungannya dengan VO2max, karena VO2max (volume maksimal $\mathrm{O}_{2}$ ) yaitu tempo tercepat dimana seseorang dapat menggunakan oksigen selama berolahraga dan merupakan cara untuk menentukan kesegaran kardiovaskuler. Seseorang yang mempunyai VO2max yang baik maka dalam penggunakan oksigen akan lebih baik sehingga kesegaran jasmaninya akan baik pula ${ }^{12}$.

Aktivitas fisik rutin memberikan dampak positif yaitu dengan berolahraga seperti senam Aerobik merupakan jenis olahraga yang banyak diminati dan melibatkan banyak orang dengan cara berkelompok, sehingga hubungan sosial terbentuk serta senam Aerobik juga olahraga yang mudah dilakukan dimana saja. Menurut penelitian Sonu Punia, Aktivitas fisik senam Aerobik 3-5 kali selama 4 minggu dapat menurunkan $4,16 \mathrm{mmHg}$ pada sistole dan 2,43 $\mathrm{mmHg}$ pada diastole. Aktivitas fisik seperti senam Aerobik terbukti dapat memperbaiki aliran darah, tekanan darah 4-9 mmHg.

Selain itu senam Aerobik dapat menguatkan daya tahan jantung paru dan membantu membuang sisa-sisa metabolisme tubuh sehingga senam Aerobik dapat meningkatkan kebugaran. Berdasarkan hasil penelitian Susiana membuktikan bahwa adanya peningkatan daya tahan jantung paru melalui nilai $\mathrm{Vo}_{2}$ max yang signifikan setelah dilakukannya latihan Aerobik selama 3 kali perminggu secara teratur $^{13}$. Dari uraian diatas maka, penelitiakan meneliti "Efektivitas Senam Aerobik Intensitas Sedang terhadap Tekanan Darah dan Kesegaran Jasmani pada Remaja Overweight di Jurusan Gizi Poltekkes Kemenkes Semarang.

\section{METODE}

Penelitian ini termasuk dalam lingkup ilmu gizi dengan landasan ilmu gizi klinik. Penelitian ini termasuk penelitian eksperimental untuk mengetahui efektivitas senam Aerobik intensitas sedang terhadap tekanan darah dan kesegaran jasmani pada remaja overweight.Lokasi penelitian dilakukan di Jurusan Gizi Poltekkes Kemenkes Semarang. Penelitian dilakukan pada bulan maretapril 2018.Penelitian ini termasuk dalam jenis penelitian true-eksperimental. Rancangan penelitian ini adalah pre test - post test control group design, dengan melihat perubahan sebelum dan sesudah dilakukan perlakuan. Pada penelitian ini subjek dikelompokkan menjadi dua yaitu kelompok perlakukan dan kelompok kontrol. Kelompok perlakuan yaitu sampel yang diberikan 
senam Aerobik Intensitas sedang, sedangkan yang menjadi kontrol adalah sampel yang tidak diberikan senam Aerobik Intensitas sedang. Populasi dalam penelitian ini adalah remaja Jurusan Gizi Poltekkes Kemenkes Semarang yang overweight. Berdasarkan perhitungan sampel, maka didapatkan sampel sebanyak 17 orang setiap kelompok.Sehingga besar sampel yang diperlukan dalam penelitian ini yaitu 17 orang untuk kelompok perlakuan dan 17 orang untuk kelompok kontrol. Total sampel penelitian yaitu 34 orang. Dengan variabel Senam aerobik Intensitas sedang, Tekanan Darah, Kesegaran Jasmani, Asupan Energi dan, Aktivitas Fisik.

HASIL

Penelitian ini termasuk dalam penelitian bidang gizi masyarakat yang meneliti pengaruh efektivitas senam aerobik intensitas sedang terhadap tekanan darah dan kesegaran jasmani pada remaja overweight di Jurusan Gizi Poltekkes Kemenkes Semarang. Penelitian dilakukan pada bulan April hingga Mei tahun 2018.

Dalam penelitian ini kelompok perlakuan diberi intervensi aktivitas fisik selama 5 minggu berupa senam aerobic intensitas sedang selama30 menit pada hari Senin, Rabu, dan Jum'at. Total senam aerobic yang harus dilakukan oleh sampel kelompok perlakuan adalah sebanyak 15 kali. Sedangkan kelompok control tidak diberikan interven siapapun.

\section{Analisis Bivariat}

Untuk mengetahui perbedaan Tekanan Darah Sistolik pada kelompok perlakuan dan kelompok kontrol sebelum dan setelah intervensi menggunakan uji Paired t-test karena data berdistribusi normal. Dan mengetahui perbedaan Tekanan Darah Diastolik pada kelompok perlakuan dan kelompok kontrol sebelum dan sesudah intervensi menggunakan uji Wilcoxon karena data berdistribusi tidak normal.

1. Pengaruh Senam Aerobik Intensitas Sedang Terhadap Tekanan Darah Sistolik dan Tekanan Darah Diastolik

Tabel 1. Pengaruh Senam Aerobik Intensitas Sedang Terhadap Tekanan Darah Sistolik dan Tekanan Darah Diastolik

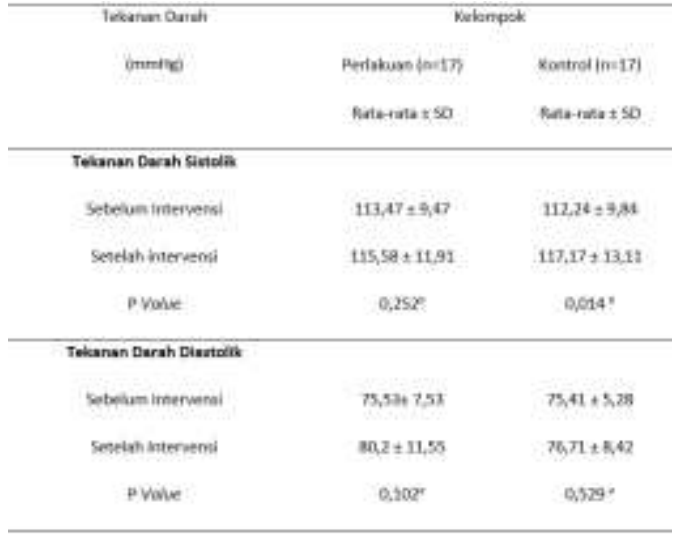

${ }^{a}$ Wilcoxon

${ }^{b}$ Paired t-test

Data perbedaan tekanan darah antar kelompok perlakuan dan kelompok kontrol diperoleh menggunakan uji independent $t$ test karena data berdistribusi normal. Data selisih tekanan darah sistolik dan tekanan Darah Diastolik sebelum dan setelah intervensi dapat dilihat pada tabel 14.

Tabel 2. Selisih Tekanan darah Sistolik dan Tekanan Darah Diastolik Sebelum dan Setelah Intervensi

\begin{tabular}{|c|c|c|c|}
\hline \multirow{2}{*}{$\begin{array}{c}\text { Teksasan Darab } \\
\text { mmits }\end{array}$} & \multicolumn{2}{|c|}{ Kelomodk } & \multirow{2}{*}{$P$ Vaise } \\
\hline & Porlakuan $[n=17]$ & Kentrol $\mid n=17)$ & \\
\hline \multicolumn{4}{|l|}{ Tekanan Darab Sistaik } \\
\hline Rata-rata + so & $2,12+7,939$ & $4,94 \div 7,396$ & $0,27 z^{e}$ \\
\hline \multicolumn{4}{|c|}{ Tekanan Darah Distolik } \\
\hline Hata-rala 5 SO & $4,71 \pm 11,044$ & $1,29 \geq 8,716$ & 0,325 \\
\hline
\end{tabular}

'Independent t-test

2. Pengaruh Senam Aerobic Intensitas Sedang Terhadap Kesegaran Jasmani

Perbedaan Kesegaran jasmani pada kelompok perlakuan dan kelompok kontrol sebelum dan setelah intervensi menggunakan uji Paired t-test karena data berdistribusi normal.

Tabel 3. Pengaruh Senam Aerobic Intensitas Sedang Terhadap Kesegaran Jasmani 


\begin{tabular}{|c|c|c|}
\hline \multirow[b]{2}{*}{ Kesegaran fovmins } & \multicolumn{2}{|c|}{ Kelompeck } \\
\hline & Periakuan $[n=17]$ & Kontrol $(n-17)$ \\
\hline & Mean ISD & Rata-tata $\pm \mathrm{SD}$ \\
\hline Sebelum interversis & $16,16 \pm 5,93$ & $12,37+5,64$ \\
\hline 5otelah intervensi & $21,84 \pm 5,25$ & $12,92 \pm 5,24$ \\
\hline P Vatue & $0,000^{\circ}$ & $0,420^{\circ}$ \\
\hline
\end{tabular}

${ }^{\mathrm{b}}$ Paired t-test

Tabel 4. Selisih Kesegaran Jasmani Sebelum

dan Setelah Intervensi

\begin{tabular}{cccc}
\hline \multirow{2}{*}{$\begin{array}{c}\text { Kesegaran } \\
\text { Jasmani }\end{array}$} & \multicolumn{2}{c}{ Kelompok } & \multirow{2}{*}{ Puafuce } \\
\cline { 2 - 3 } & Perlakuan $(0=17)$ & Kantrol $(n=17)$ & \\
\hline Rata-rata \pm SD & $5,68 \pm 3,05$ & $0,54 \pm 2,70$ & 0,000 \\
\hline
\end{tabular}

c uji menggunakan Independent t-test dan signifikan pada $\mathrm{p}<0,05$

\section{PEMBAHASAN}

Diketahui untuk rata-rata asupan antara kelompok kontrol dengan kelopok perlakuan tidak jauh berbeda. Dan rata-rata aktifitas fisik yang diukur dengan metode baecke rata-rata paling tinggi pada minggu ke 1. Rata-rata tekanan sistolik sebelum intervensi dan setelah intervensi berdasarkan hasil analisis statistik menggunakan uji Paired t-test diperoleh hasil bahwa terdapat perbedaan pada kelompok kontrol dengan $p=$ $0,014$ ( $p>0,05)$.

Rata-rata tekanan darah diastolik sebelum dan setelah intervensi pada kelompok perlakuan diperoleh hasil bahwa tidak ada perbedaan tekanan diastolik sebelum dan sesudah intervensi senam aerobik intensitas sedang, hal ini dibuktikan $p=$ $0,102(p>0,05)$.

Rata-rata tekanan darah diastolik sebelum intervensi pada kelompok kontrol adalah 75,41 \pm $5,28 \mathrm{mmHg}$, sedangkan setelah intervensi 76,71 \pm $8,42 \mathrm{mmHg}$. Diperoleh hasil bahwa tidak terdapat perbedaan tekanan darah diastolik sebelum dan setelah intervensi pada kelompok kontrol yang ditunjukkan dengan nilai $p=0,529(p>0,05)$.

Berdasarkan dari tabel 14, rata-rata selisih tekanan darah sistolik sebelum dan sesudah diberikan perlakuan senam aerobik intensitas sedang kelompok perlakuan adalah 2,12 $\pm 7,339$ $\mathrm{mmHg}$, sedangkan pada kelompok kontrol 4,94 \pm $7,386 \quad \mathrm{mmHg}$. Dilakukan uji statistik menggunakakan uji independent t-test diperoleh nilai $p=0,272(p>0,05)$. Rata-rata selisih tekanan diastolik sebelum dan setelah diberikan perlakuan pada kelompok perlakuan adalah 4,71 $\pm 11,044$
$\mathrm{mmHg}$, sedangkan pada kelompok kontrol adalah $1,29 \pm 8,716 \mathrm{mmHg}$. Dilakukan uji statistik diperoleh nilai $p=0,325 \quad(p>0,05)$. Sehingga dapat menunjukkan tidak ada perbedaan selisih tekanan darah sistolik dan tekanan darah diastolik.

Setelah dilakukan penelitian, menunjukkan tidak ada perbedaan pada tekanan darah sistolik maupun diastolik setelah diuji dengan uji Paired t-test (data berdistribusi normal). Untuk hasil yang efektif diperlukan senam yang rutin. Ketidakteraturan sampel mengikuti senam dikarenakan sampel memiliki jadwal kuliah yang padat sehingga tidak dapat mengikuti senam secara teratur. Dan pada saat pengukuran tekanan darah berada di lab psg lantai tiga dijurusan gizi sehingga pada saat pengukuran tekanan darah subjek ada yang meningkat.

Untuk mendapatkan hasil yang efektif dengan senam secara teratur didukung oleh penelitian Punia et all bahwa apabila senam aerobik dilakukan secara teratur 3-5 kali selama 4 minggu akan efektif menurunkan tekanan darah yaitu 4,16 $\mathrm{mmHg}$ pada sistole dan 2,43 $\mathrm{mmHg}$ pada diastole. Dari hasil analisis uji Paired t-testminimal terdapat penurunan tekanan darah dan menormalkan tekanan darah pada kelompok perlakuan, meskipun belum maksimal.

Berdasarkan tabel 15 bahwa rata-rata senam kesegaran Jasmani sebelum diberikan intervensi pada kelompok perlakuan adalah 16,16 \pm 5,93 , sedangkan setelah intervensi adalah 21,84 \pm 5,25 . Untuk mengetahui perbedaan kesegaran jasmani sebelum dan sesudah intervensi menggunakan uji Paired t-test sehingga diperoleh hasil terdapat perbedaan kesegaran Jasmani sebelum dan setelah senam aerobik intensitas sedang kelompok perlakuan, hal ini dibuktikan dengan nilai $p=0,000(p<0,05)$.

Rata-rata kesegaran jasmani sebelum intervensikelompok kontrol (12,37 \pm 5,64), sedangkan setelah intervensi kelompok kontrol $(12,92 \pm 5,24)$. Diperoleh hasil bahwa tidak terdapat perbedaan kesegaran jasmani sebelum dan sesudah intervensi pada kelompok kontrol, hal ini dibuktikan dengan nilai $p=0,420(p>0,05)$.

Hasil analisis kesegaran jasmani dengan menggunakan uji Paired $t$-test, didapatkan $\mathrm{p}$-value kelompok perlakuan $(0,000)$ menunjukkan terdapat perbedaan yang signifikan dari sebelum diberikan intervensi dan sesudah diberikan intervensi dari senam aerobik intensitas sedang pada kesegaran jasmani sampel. Dari hasil menunjukkan kesegaran jasmani sampel pada kelompok perlakuan meningkat. Sedangkan pada kelompok kontroldiketahui $p$ value 0,420 yang menunjukkan bahwa tidak ada perbedaan pada kesegaran jasmaninya. 
Didukung dari Penelitian Nandhini $P$ bahwa rata-rata kesegaran jasmani (Vo2max) efektif meningkat. Sebelum diberikan intervensi selama 8 minggu senam aerobik yaitu 22,15 dan setelah diberikan senam menjadi $25,08^{14}$.

Hal ini karena efek dari olahraga aerobik adalah kebugaran kardio respiratori, karena olahraga tersebut mampu meningkatkan ambilan oksigen, meningkatkan kapasitas darah untuk mengangkut oksigen dan denyut nadi menjadi lebih rendah saat istirahat maupun beraktifitas dan aerobik bisa meningkatkan jumlah kapiler, menurunkan jumlah lemak dalam darah dan meningkatkan enzim pembakar lemak. Sehingga hal ini mampu meningkatkan kesegaran jasmani individu ${ }^{15}$.

Berdasarkan tabel 15 bahwa rata-rata senam kesegaran Jasmani sebelum diberikan intervensi pada kelompok perlakuan ( 16,16 $\pm 5,93)$, setelah intervensi $(21,84 \pm 5,25)$. Untuk mengetahui perbedaan kesegaran jasmani sebelum dan sesudah intervensi menggunakan uji Paired $t$ test sehingga diperoleh hasil terdapat perbedaan kesegaran Jasmani sebelum dan setelah senam aerobik intensitas sedang kelompok perlakuan, hal ini dibuktikan dengan nilai $p=0,000(p<0,05)$.

Rata-rata kesegaran jasmani sebelum intervensi kelompok kontrol (12,37 \pm 5,64), sedangkan setelah intervensi kelompok kontrol $(12,92 \pm 5,24)$. Untuk mengetahui perbedaan kesegaran jasmani sebelum dan setelah intervensi pada kelompok kontrol menggunakan uji Paired $t$ test diperoleh hasil bahwa tidak terdapat perbedaan kesegaran jasmani sebelum dan sesudah intervensi pada kelompok kontrol, hal ini dibuktikan dengan nilai $p=0,420(p>0,05)$.

\section{KESIMPULAN}

Berdasarkan hasil penelitian yang dilakukan di Jurusan Gizi Poltekkes Kemenkes Semarang pada tahun 2018 disimpulkan sebagai berikut :

1. Tidak terdapat perbedaan tekanan darah sistolik pada kelompok perlakuan sebelum dan sesudah pemberian senam aerobik intensitas sedang ( $p$ value 0,252). Tidak terdapat perbedaan tekanan darah sistolik pada kelompok kontrol sebelum dan sesudah pemberian senam aerobik intensitas sedang dengan ( $p$ value 0,014 ).

2. Tidak terdapat perbedaan tekanan darah diastolik pada kelompok perlakuan sebelum dan sesudah pemberian senam aerobik intensitas sedang ( $p$ value 0,102 .)

Tidak terdapat perbedaan tekanan darah diastolik pada kelompok kontrol sebelum dan sesudah pemberian senam aerobik intensitas sedang ( $p$ value 0,529 )

3. Ada perbedaan kesegaran jasmani pada kelompok perlakuan sebelum dan sesudah pemberian senam aerobik intensitas sedang $(p$ value 0,000$) \quad(p>0,05)$ dan tidak terdapat perbedaan kesegaran jasmani kelompok kontrol sebelum dan sesudah pemberian senam aerobik intensitas sedang dengan $\mathrm{p}$ value kelompok perlakuan 0,420$),(p>0,05)$

4. Tidak terdapat perbedaan penurunan Tekanan darah Sistolik antar kelompok perlakuan dan kelompok kontrol ( $p$ value 0,272 )

5. Tidak terdapat perbedaan penurunan Tekanan darah Diastolik antar kelompok perlakuan dan kelompok kontrol ( $p$ value 0,325) Ada perbedaan peningkatan kesegaran jasmani pada kelompok perlakuan dan kelompok kontrol ( $p$ value 0,000 ).

\section{SARAN}

Sebaiknya perlu dilakukan penelitian serupa dengan senam frekuensi lebih teratur dan dilakukan monitoring setiap minggu untuk melihat efektivitas dari intervensi.

\section{DAFTAR PUSTAKA}

1. Departemen Kesehatan Indonesia. Profil Kesehatan Indonesia. Jakarta: Depkes RI; 2012.

2. Nurusalma N. Faktor-faktor yang Berhubungan dengan Status Gizi Karyawan Rumah Sakit dr. H. Marzoeki Mahdi Bogor. Depok: FKMUI; 2006.

3. Badan Penelitian dan Pengembangan Kesehatan. Riset Kesehatan Dasar (RISKESDAS) 2013. Lap Nas 2013. 2013;1-384.

4. Jaelani, M., Larasati, M. D., Rahmawati, A. Y., \& Ambarwati, R. (2018). Efektifitas Aktivitas Peer Group terhadap Penurunan Berat Badan dan Persen Lemak Tubuh pada Remaja Overweight. Jurnal Kedokteran Brawijaya, 30(2), 127-132.

5. Fitriani L. Pengaruh Aktivitas Peer Group Terhadap Penurunan Berat Badan, Tekanan Darah, dan Kesegaran Jasmani Pada Mahasiswi Overweight di Jurusan Gizi Poltekkes Kemenkes Semarang. Skripsi. 2017;

6. Soegih R, Wiramihardja K kK. Obesitas Permasalahan dan Terapi Praktis. Jakarta: Sagung Seto; 2009.

7. Karen L. McNiece $M$ information about the author MKLM the author MKLM, Poffenbarger TS, Turner JL, , Kathy D. Franco B, , Jonathan M. Sorof M, , Ronald J. Portman M. Prevalence 
of Hypertension and Pre-Hypertension among Adolescents. PlumX Metrics. 2007;150(6):640-644.e1.

8. Martiani A, Lelyana R. Faktor Risiko Hipertensi Ditinjau dari Kebiasaan Minum Kopi. J Nutr Coll. 2012;I:79-84.

9. Iqbal R, Ahmad Z, Malik F, Mahmood S. A Statistical Analysis of Hypertension as Cardiovascular Risk Factor. Middle East J Sci Res. 2012;12(1):19-22.

10. Ginting AA. Survey Tingkat Kebugaran Jasmani Berdasarkan Indeks Massa Tubuh pada Siswa SMP Negeri 1 Kabanjahe Tahun Ajaran 2011/2012. Skripsi. Medan: Universitas Negeri Medan; 2012.

11. Utari A. Tingkat Kesegaran Jasmani pada Anak
Usia 12-14 Tahun." Skripsi. Semarang. Semarang: Fakultas Kedokteran UNDIP; 2007.

12. Sudarno SP. Pendidikan Kesegaran Jasmani. Jakarta: Dep Dikbud; 1993.

13. Candrawati S, Sulistyoningrum E, Pranasari N, Fisiologi L, Kedokteran F, Jenderal $U$, et al. Senam Aerobik Meningkatkan Daya Tahan Jantung Paru dan Fleksibilitas Aerobic Dance Increase the Cardiorespiratory Endurance and Flexibility. 29(1):69-73.

14. Nandhini P. Effect Of Aerobic Dance Training On Maximal Oxygen Uptake ( Vo 2 max ) Of College Women Abstract : 2013;2(6):823-7.

15. Pekik I D. Bugar dan Sehat dengan Berolahraga. Yogyakarta: Andi Offset; 2004. 